\title{
PENGARUH PENERAPAN CORPORATE SOCIAL RESPONSIBILITY (CSR), CORPORATE IMAGE, DAN KEPUTUSAN NASABAH TERHADAP LOYALITAS NASABAH
}

\author{
Ahmad Faqihudin 1 \\ ahmadfaqihudin34@gmail.com \\ Dr. Meinarni Asnawi, SE., M.Si, CBV, CMA ${ }^{2}$ \\ Bill J. C. Pangayow, SE., M.Si., Ak ${ }^{3}$ \\ Jurusan Akuntansi, Fakultas Ekonomi dan Bisnis Universitas Cenderawasih
}

\begin{abstract}
This study aims to examine the influence of corporate social responsibility (CSR) implementation, corporate image, and customer satisfaction, on customer loyalty. Variables independent were used in this study namely Corporate Social Responsibility (CSR), corporate image, and customer satisfaction. , as well as one dependent variable of customer loyalty.

Customers of PT Bank Rakyat Indonesia Jayapura are used as the population in this study. The convenience sampling with a sample of 30 respondents is the technique of sampling method in this study. This study uses a double linear regression analysis to analyses data. The analysis tool used is SPSS version 23.

The results of this research demonstrate the implementation of Corporate Social Responsibility (CSR) has positively and significantly affects customer loyalty. Corporate Image has a positive and significant impact on customer loyalty. And customer satisfaction has a positive but does no significant impact on customer loyalty.
\end{abstract}

Keywords : corporate social responsibility (CSR), corporate image, customer satisfaction and customer loyalty.

\section{PENDAHULUAN}

Perkembangan zaman dan kemajuan teknologi yang begitu pesat membuat para manajer harus berpikir keras agar mampu bertahan dalam persaingan usaha. Adapun yang terjadi di Indonesia khususnya wilayah Kota Jayapura, kini persaingan di sektor perbankan semakin meningkat, yaitu ditunjukkan dengan banyaknya perusahaan perbankan baru yang bermunculan.

Pada saat sekarang ini, sektor keuangan khususnya industri perbankan mulai memahami perilaku nasabahnya yang mana para nasabah tersebut sekarang ini lebih mementingkan nilai (value) yang dapat diterimanya dari bank yang mereka menjadi nasabahnya, dimana dengan adanya nilai tesebut diharapkan mampu membuat nasabah itu menjadi nasabah yang loyal, bukan lagi memperhatikan pertimbangan pemberian faktor bunga atau lengkap dan canggihnya suatu produk perbankan yang ditawarkan oleh bank.

Loyalitas nasabah adalah kesetiaan dan perasaaan positif nasabah terhadap bank yang ditandai dengan keteraturan nasabah dalam melakukan transaksi secara berulang dan lamanya penggunaan suatu produk. Kebiasaan ini termotivasi secara subjektif dan sulit diubah. Nasabah yang mempunyai loyalitas akan terus melanjutkan hubungannya dengan menggunakan produk bank tersebut.

\footnotetext{
$\overline{{ }^{1} \text { Alumni Jurusan Akuntansi FEB Uncen }}$

${ }^{2}$ Dosen Jurusan Akuntansi FEB Uncen

3 Dosen Jurusan Akuntansi FEB Uncen
} 
Fenomena menarik yang terjadi pada perbankan menunjukkan bahwa Bank Rakyat Indonesia (BRI) adalah salah satu bank terbesar di Kota Jayapura, memiliki kantor hingga ke pelosok pedesaan dan telah mendapat kepercayaan oleh masyarakat Kota Jayapura pada umumnya, tetapi yang terjadi bahwa perilaku nasabah setelah membuka tabungan di BRI, mereka kembali membuka tabungan pada bank lain. Hal ini mengisyratkan bahwa dalam upaya untuk mempertahankan dan meningkatkan loyalitas nasabahnya, maka BRI harus mampu dalam memberikan pelayanan yang prima bagi nasabahnya.

Upaya tersebut dapat dilakukan dengan menawarkan produk dengan imbal hasil yang bersaing, menciptakan inovasi produk, penentuan strategi pemasaran yang tepat sasaran, menyediakan fasilitas transaksi yang mudah dan aman, kualitas pelayanan yang baik, serta memberikan suatu kontribusi pada masyarakat melalui kegiatan tanggungjawab sosial perusahaan.

Corporate Social Responsibility (CSR), yaitu suatu bentuk pertanggungjawaban sosial perusahaan terhadap masyarakat secara luas. Seluruh perusahaaan yang ada diharapkan dapat memberikan suatu bentuk pertanggungjawaban sosial yang diungkapkan dalam laporan keuangan tahunan perusahaan dan diatur oleh perundang- undangan serta Peraturan Pemerintah yang berlaku. Hal ini tercantum dalam Undang-Undang No. 40 tahun 2007 tentang Perseroan Terbatas pasal 74 mengenai Tanggung Jawab Sosial dan Lingkungan, dan Peraturan Pemerintah No. 47 Tahun 2012 tentang Tanggung Jawab Sosial Dan Lingkungan Perseroan Terbatas.

Penyaluran CSR tersebut berupa tujuh unit mobil penyuluhan dan ambulance, serta mobil operasional yang masing-masing diberikan kepada Pemerintah Daerah Papua, Kepolisian Daerah Papua, Polresta Papua Barat, RSUD Papua, RSUD Papua Barat ,RS TNI AD di Jayapura, dan mobil operasional untuk Universitas Cenderawasih.

BRI juga menyalurkan CSR di bidang pendidikan berupa sumbangan untuk Universitas Ottow Geisler Jayapura, dan memberikan bantuan berupa beasiswa kepada 120 orang mahasiswa di Universitas Cenderawasih, Universitas Sains dan Tekhnologi Jayapura, dan beasiswa yang diberikan kepada putera daerah Papua yang saat ini sedang mengenyam pendidikan di sejumlah universitas ternama di Pulau Jawa. Kemudian CSR di bidang sosial berupa sumbangan untuk sarana ibadah kepada masjid dan gereja, penyediaan sarana air bersih, pasar murah dan renovasi rumah veteran di Polimak, Jayapura.

Penerapan Corporate Social Responsibility (CSR) oleh PT Bank Rakyat Indonesia cabang kota Jayapura, selain sebagai bentuk apresiasi terhadap masyarakat diharapkan dapat dijadikan sebagai sarana peningkatan citra perbankan di mata masyarakat, karena terdapat banyak sektor industri serupa berskala nasional baik milik pemerintah maupun swasta memiliki nasabah yang cukup besar sehingga citra perbankan perlu ditingkatkan.

\section{Tinjauan Pustaka}

\subsection{Teori Legitimasi (Legitimacy Theory)}

Teori legitimasi merupakan suatu gagasan tentang kontrak sosial antara perusahaan dengan masyarakat. Menurut teori ini, keberlangsungan hidup perusahaan dapat ditentukan dengan melakukan pengungkapan aktivitas sosial perusahaan sehingga dapat diterima oleh masyarakat.

Hal lain yang dijelaskan oleh teori ini adalah kegiatan pengungkapan aktivitas sosial yang dilakukan oleh perusahaan harus secara optimal dalam hal pelaksanaannya dan pengungkapannya sehingga dapat diterima oleh masyarakat. Kegiatan pengungkapan ini dapat melegitimasi setiap aktivitas sosial yang dilakukan kepada masayarakat dan juga menunjukkan kepatuhan perusahaan terhadap peraturan yang berlaku. 


\subsection{Teori Stakeholder (Stakeholder Theory)}

Stakeholder menggambarkan pihak-pihak yang terlibat secara langsung dengan perusahaan yang mempengaruhi aktivitas bisnis perusahaan, sebagai contoh misalnya karyawan, masyarakat, perusahaan pesaing dan pemerintah (Purwanto, 2011). Daud dan Abrar (2008) menjelaskan bahwa pihak-pihak stakeholder tersebut merupakan pihak yang signifikan mempunyai kepentingan terhadap pengungkapan informasi yang dilakukan oleh perusahaan.

Teori stakeholder juga menjelaskan bahwa perusahaan seharusnya memberikan dampak kepada masyarakat disekitarnya dalam melakukan aktivitas binisnya, dimana perusahaan bukanlah dianggap sebagai suatu individual terpisah dari para stakeholdernya sehingga harus memberikan manfaat kepada para stakeholdernya. Oleh sebab itu, dukungan dari para stakeholder dapat mempengaruhi keberadaan dari suatu perusahaan (Ghozali dan Chariri, 2007).

\subsection{Corporate Social Responsibility}

Corporate Social Responsibility (CSR) adalah suatu pengaruh yang lebih luas dari perusahaan kepada masyarakat untuk keuntungan perusahaan dan masyarakat secara keseluruhan (Marsden dan Andriof dalam majalah Percik, Oktober 2005).

The Word Business Council for Sustainable Development (WBCSD) dalam Wibisono (2007: 7), CSR atau tanggung jawab sosial perusahaan adalah komitmen dunia usaha untuk terus menerus bertindak secara etis, beroperasi secara legal dan berkontribusi untuk peningkatan ekonomi, bersamaan dengan peningkatan kualitas hidup karyawan dan keluarganya sekaligus juga pneingkatan kualitas komunitas lokal dan masyarakat secara lebih luas. Konsep ini menawarkan keseimbangan antara perhatian terhadap aspek ekonomis dan perhatian terhadap aspek sosial serta lingkungan.

\subsection{Corporate Image}

Citra perusahaan diawali dengan persepsi publik dari kegiatan yang dilakukan perusahaan yang dapat membentuk persepsi customer dari waktu ke waktu (Gregory \& Wiechmann, 2001). Terkait dengan ini, Dowling (2001) menyatakan bahwa citra perusahaan mencerminkan perepsi publik tentang tanggung jawab sosial yang dilakukan perusahaan melalui tindakan pemasaran.

Menurut Susanto dalam (Saputri, 2010:18), citra perusahaan terbentuk dari asosiasi antara perusahaan dengan sekumpulan atribut positif maupun negatif, misalnya perusahaan diasosiasikan dengan atribut-atribut bermutu, layanan baik, tetapi kurang memiliki tanggung jawab sosial. Jadi, sajatinya corporate image atau citra perusahaan berada dalam benak stakeholdernya dimana atribut yang menonjol akan menentukan reputasi perusahaan.

\subsection{Kepuasan Nasabah}

Menurut (Zeithaml dan Bitner, 2000:75) kepuasan adalah respon atau tanggapan konsumen mengenai pemenuhan kebutuhan. Kepuasan merupakan penilaian mengenai ciri atau keistimewaan produk atau jasa atau produk itu sendiri yang menyediakan tingkat kesenangan konsumen berkaitan dengan pemenuhan kebutuhan konsumen.

Kotler dan Amstrong dalam Atmojo (2010: 16), kepuasan pelanggan adalah tingkatan dimana anggapan kinerja (percevid performance) produk akan sesuai dengan harapan seorang pelanggan. Kinerja produk yang jauh lebih rendah dibandingkan harapan pelanggan maka pembelinya tidak puas, sebaliknya bila kinerja sesuai dengan harapan atau melebihi harapan, pembelinya merasa puas atau merasa amat gembira. Terkait dengan perbankan maka nasabah akan memilih bank yang mampu untuk memberikan kepuasan, baik itu dalam aktivitas layanan maupun dalam fitur-fitur produk yang ditawarkan. 


\subsection{Loyalitas Nasabah}

Menurut Griffin (1995) loyalitas konsumen adalah komitmen yang kuat dari konsumen, sehingga bersedia melakukan pembelian ulang terhadap produk atau jasa yang disukai secara konsisten dan dalam jangka panjang, tanpa terpengaruh oleh situasi dan usaha marketing dari produk lain yang berusaha untuk beralih ke produk lain tersebut.

Lovelock (1999) menjelaskan bahwa tingkat kesetiaan dari para konsumen terhadap suatu barang atau jasa merek tertentu tergantung pada beberapa faktor yaitu: besarnya biaya untuk berpindah ke merek barang atau jasa yang lain, adanya kesamaan mutu, kuantitas atau pelayanan dari jenis barang atau jasa pengganti, adanya risiko perubahan biaya akibat barang atau jasa pengganti dan berubahnya tingkat kepuasan yang didapat dari merek baru dibanding dengan pengalaman terhadap merek sebelumnya yang pernah dipakai.

\subsection{Penelitian Terdahulu dan Pengembangan Hipotesis}

\section{Pengaruh Corporate Social Responsibility (CSR) terhadap Loyalitas Nasabah}

Penelitian (Rahmasari, 2012) yang menyimpulkan bahwa terdapat pengaruh positif dan signifikan penerapan Corporate Social Responsibility (CSR) terhadap loyalitas nasabah. Berdasarkan hasil penelitian diatas, dengan demikian peneliti menyimpulkan bahwa semakin banyak manfaat yang didapatkan oleh nasabah dari penerapan Corporate Social Responsibility (CSR) yang dilakukan perbankan, maka akan menumbuhkan dan meningkatkan loyalitas nasabah. Hipotesis yang diajukan dalam penelitian ini berdasarkan penelitian terdahulu adalah:

H1: Terdapat pengaruh positif dan signifikan penerapan Corporate Social Responsibility (CSR) terhadap Loyalitas Nasabah.

\section{Pengaruh Corporate Image (CI) terhadap Loyalitas Nasabah (LN)}

Penelitian (Rahmasari, 2012) yang berjudul Pengaruh Penerapan Corporate Social Responsibility (CSR) terhadap loyalitas nasabah dengan citra perbankan dan sikap sebagai variabel intervening (Kasus pada PT Bank Rakyat Indonesia (Persero) Tbk. Cabang Bantul), menyimpulkan bahwa terdapat pengaruh positif dan signifikan citra perbankan terhadap loyalitas nasabah. Berdasarkan hasil penelitian diatas, peneliti menyimpulkan bahwa semakin baik corporate image, maka loyalitas nasabah akan meningkat. Hipotesis yang diajukan dalam penelitian ini berdasarkan penelitian terdahulu adalah:

H2: Terdapat pengaruh positif dan signifikan corporate image terhadap loyalitas nasabah.

\section{Pengaruh Kepuasan Nasabah (KN) terhadap Loyalitas Nasabah (LN)}

Penelitian (Sulastri, 2015) menyimpulkan bahwa analisis data dalam penelitian menunjukkan variabel kepuasan mempunyai pengaruh yang positif dan signifikan terhadap loyalitas nasabah. Berdasarkan hasil penelitian diatas, dengan demikian peneliti menyimpulkan bahwa semakin tinggi tingkat kepuasan yang dirasakan nasabah, maka akan semakin tinggi pula tingkat loyalitas nasabah. Hipotesis yang diajukan dalam penelitian ini berdasarkan penelitian terdahulu adalah:

H3: Terdapat pengaruh positif dan signifikan kepuasan nasabah terhadap loyalitas nasabah.

\section{METODOLOGI PENELITIAN}

\subsection{Populasi dan Sampel}

Populasi yang digunakan dalam penelitian ini yaitu seluruh nasabah PT Bank Rakyat Indonesia Cabang Kota Jayapura. Karena jumlah populasi yang sangat besar, sehingga diperlukan efisiensi waktu dan biaya, maka tidak semua nasabah menjadi objek dalam penelitian ini. Oleh karena itu dilakukan pengambilan sampel. 
Teknik pengambilan sampel yang digunakan dalam penelitian ini yaitu Convenience sampling.

Teknik Convenience sampling adalah teknik penentuan sampel berdasarkan kebetulan, artinya unit atau nasabah yang peneliti temui pada saat pengumpulan data dilakukan. Alasan pemilihan teknik ini adalah untuk memudahkan proses pengambilan sampel karena jumlah nasabah yang sangat banyak.

Jumlah sampel dalam penelitian ini adalah 100 responen/nasabah. Hair et al, dalam Putro (2009:43) menyatakan bahwa jumlah sampel minimum yang digunakan dalam analisis faktor adalah 50 responden, tetapi jumlah sampel sebaiknya lebih besar dari 100 responden.

\subsection{Skala Pengukuran}

Skala pengukuran dalam penelitian ini menggunakan Skala Likert. Skala likert digunakan untu mengukur sikap, pendapat dan persepsi seseorang tentang fenomena sosial (Sugyiono, 2010:93). Dengan skala likert, maka variabel yang diukur dijabarkan menjadi indikator variabel. Kemudian indikator tersebut dijadikan titik tolak untuk menyusun item- item instrumen yang berupa pernyataan atau pertanyaan.

Untuk mengukur variabel dalam penelitian ini menggunakan skala likert dengan interval 1 sampai 5 dengan kriteria, "sangat setuju" diberi skor 5, "setuju" diberi skor 4, "netral" diberi skor 3, "tidak setuju" diberi skor 2, dan "sangat tidak setuju" diberi skor 1.

\subsection{Analisis Data}

Alat yang digunakan untuk menguji data dalam peneitian ini adalah SPSS versi 23. Uji isntrumen yang akan dalam penelitian ini diantaranya adalah uji reliabilitas, uji validitas, uji asumsi klasik, uji regresi linier berganda, dan uji statistik, uji statistic t dan uji koefisien determinasi $\left(\mathrm{R}^{2}\right)$. Berikut ini adalah persamaan regresi linear berganda yang digunakan untuk melakukan pengujian hipotesis:

$$
\mathrm{Y}=\beta 0+\beta 1 \mathrm{X} 1+\beta 2 \mathrm{X} 2+\beta 3 \mathrm{X} 3+e
$$

Keterangan:

$\mathrm{Y}=$ Loyalitas Nasabah

$\beta 0=$ konstanta $($ constant $)$

$\beta 1-3=$ koefisien regresi

$\mathrm{X} 1$ = Corporate Social Responsibility

$\mathrm{X} 2$ = Corporate Image

X3 = Kepuasan nasabah

$e=$ Residual atau prediction error

\section{HASIL PENELITIAN DAN PEMBAHASAN}

\subsection{Gambaran Umum Responden}

Dalam penelitian ini yang dijadikan sebagai objek penelitian adalah seluruh nasabah Bank Rakyat Indonesia yang ada di Jayapura. Studi yang dilakukan oleh peneliti adalah studi lapangan, yaitu dengan cara membagikan kuesioner secara langsung kepada nasabah yang akan melakukan transaksi maupun yang sudah melakukan transaksi diarea perbankan pada saat jam kerja. Data kuesioner yang di sebarkan sebanyak 50 kuesioner, sedangankan kuesioner yang tidak kembalikan sebanyak 20 kuesioner, maka jumlah kuesioner yang dapat diolah dan di analisis sebanyak 30 kuesioner, dengan tingkat pengembalian sebesar $60 \%$. 


\subsection{Statistik Deskriptif}

Tabel 1

Hasil Pengujian Statistik Deskriptif

\begin{tabular}{|l|r|r|r|r|r|}
\hline \multicolumn{1}{|c|}{ Descriptive Statistics } & \\
\hline $\mathrm{N}$ & & Minimum & Maximum & Mean & Std. Deviation \\
$\mathrm{CSR}$ & 30 & 48 & 89 & 76.57 & 8.378 \\
$\mathrm{KN}$ & 30 & 30 & 40 & 33.83 & 3.163 \\
LN & 30 & 26 & 39 & 33.77 & 2.487 \\
Valid N (listwise) & 30 & 24 & 39 & 32.50 & 3.060 \\
\hline
\end{tabular}

Sumber : Data Primer yang diolah 2019

Variabel Corporate Social Responsibility (CSR) mempunyai bobot jawaban antara lain dengan nilai minimum 48, dan nilai maximum sebesar 89 dengan nilai rata-rata 76,57 dan nilai standar deviasi 8,378. Variabel Corporate Image (CI) memiliki bobot jawaban dengan nilai minimum sebesar 30, nilai maximumnya sebesar 40 dengan nilai rata-rata sebesar 33,83 dan dengan nilai standar deviasinya sebesar 3,163. Variabel Kepuasan Nasabah (KN) dengan bobot nilai minimum sebesar 26, nilai maximum 39, dengan nilai rata-rata sebesar 33,77 dan nilai standar deviasi sebesar 2,487. Variabel Loyalitas Nasabah (LN) memiliki bobot jawaban dengan nilai minimum 24, sedangkan nilai maximumnya 39, dengan nilai rata-rata sebesar 32.50 dan nilai standar deviasi sebesar 3,060.

\subsection{Hasil Pengujian Hipotesis}

\section{$\underline{\text { Uji Statistik t }}$}

Table 2

Hasil Uji Statistik t

\begin{tabular}{|c|c|c|c|c|c|c|}
\hline \multicolumn{7}{|c|}{ Coefficients $^{\mathrm{a}}$} \\
\hline \multirow{2}{*}{\multicolumn{2}{|c|}{ Model }} & \multicolumn{2}{|c|}{$\begin{array}{c}\text { Unstandardized } \\
\text { Coefficients } \\
\end{array}$} & \multirow{2}{*}{$\frac{\text { Standardized Coefficients }}{\text { Beta }}$} & \multirow[b]{2}{*}{$\mathrm{t}$} & \multirow[b]{2}{*}{ Sig. } \\
\hline & & $\mathrm{B}$ & Std. Error & & & \\
\hline \multirow[t]{4}{*}{1} & (Constant) & -5.710 & 5.405 & & -1.056 & .301 \\
\hline & CSR & .220 & .037 & .601 & 5.864 & .000 \\
\hline & $\mathrm{CI}$ & .461 & .101 & .477 & 4.575 & .000 \\
\hline & $\mathrm{KN}$ & .171 & .127 & .139 & 1.348 & .189 \\
\hline
\end{tabular}

a. Dependent Variable: LN

Sumber : Data Primer yang diolah 2019

Berdasarkan output tabel di atas, menunjukkan bahwa:

1. Nilai Sig. untuk CSR adalah sebesar $0,000(\mathrm{p}<0,05)$ maka dari itu hipotesis diterima, artinya variabel CSR berpengaruh signifikan terhadap Loyalitas nasabah.

2. Nilai Sig. untuk CI adalah sebesar $0,000(\mathrm{p}<0,05)$ maka dari itu hipotesis diterima, artinya variabel CI berpengaruh signifikan terhadap Loyalitas nasabah.

3. Nilai Sig. untuk KN adalah sebesar 0,189 ( $>>0,05)$ maka dari itu hipotesis ditolak, artinya variabel $\mathrm{KN}$ tidak berpengaruh signifikan terhadap Loyalitas nasabah. 


\section{$\underline{\text { Uji Koefisien Determinasi }\left(\mathrm{R}^{2}\right)}$}

\section{Tabel 3}

\section{Hasil Uji Koefisien Determinasi $\left(\mathbf{R}^{2}\right)$}

\begin{tabular}{|c|c|c|c|c|}
\hline \multicolumn{5}{|c|}{ Model Summary } \\
\hline Model & $\mathrm{R}$ & R Square & $\begin{array}{c}\text { Adjusted R } \\
\text { Square }\end{array}$ & $\begin{array}{l}\text { Std. Error of the } \\
\text { Estimate }\end{array}$ \\
\hline 1 & $.856^{\mathrm{a}}$ & .734 & .703 & 1.668 \\
\hline
\end{tabular}

a. Predictors: (Constant), KN, CSR, CI

Sumber : Data Primer yang diolah 2019

Berdasarkan hasil perhitungan estimasi regresi, diperoleh nilai koefisien determinasi adjusted $\mathrm{R}$ square sebesar 0,703 artinya 70,3\% variasi variabel dependen yaitu loyalitas nasabah dapat dijelaskan oleh variasi dari ketiga variabel independen yaitu, Corporate Social Responsibility, Corporate Image, dan Kepuasan nasabah, sedangkan sisanya $(100 \%-70,3 \%=29,7 \%)$ ditentukan oleh sebab-sebab lain di luar model yang tidak terdeteksi dalam penelitian ini.

\subsection{Pembahasan}

\section{Pengaruh Corporate Social Responsibility (CSR) terhadap Loyalitas Nasabah}

Corporate Social Responsibility (CSR) berpengaruh positif dan signifikan terhadap loyalitas nasabah Setiap kegiatan Corporate Social Responsibility yang dilakukan oleh perbankan tidak hanya memberikan manfaat untuk masyarakat sekitar, tetapi juga memberikan manfaat untuk perbankan sendiri karena dengan adanya kegiatan tersebut masyarakat akan menilai kegiatan yang telah dilakukan oleh perbankan apakah baik ataukah tidak. Apabila kegiatan tersebut dinilai baik maka dapat menarik perhatian cukup besar bagi calon nasabah dan semakin meningkatkan intensitas transaksi nasabah dalam menggunakan produk dan jasa perbankan.

Hal tersebut menjadi salah satu aspek pembentuk loyalitas nasabah yang merupakan centrality atau dapat diartikan dengan calon nasabah menunjukkan sikap berupa nilai yang telah mereka anggap baik terhadap kegiatan Corporate Social Responsibility yang telah dilakukan oleh perbankan. Dari hasil penelitian ini menunjukkan hasil yang positif dan signifikan antara Corporate Social Responsibility (CSR) terhadap loyalitas nasabah. Penelitian ini sejalan dengan penelitian yang dilakukan oleh Lomi \& Yasa (2015) di Denpasar tentang pengaruh Corporate Social Responsibility (CSR) terhadap Loyalitas Nasabah bahwa kegiatan CSR yang telah dikomunikasikan dengan baik akan meningkatkan loyalitas nasabah.

\section{Pengaruh Corporate Image (CI) terhadap Loyalitas Nasabah (LN)}

Corporate image berpengaruh positif dan signifikan terhadap loyalitas nasabah Citra perbankan yang baik merupakan suatu hal yang sangat kuat untuk menarik minat nasabah dalam memilih produk dan jasa perbankan. Citra yang positif akan memberikan arti yang baik terhadap produk atau jasa suatu perbankan dan akan meningkatkan penjualan. Begitupun sebaliknya jika citra yang negatif akan menyebabkan penurunan penjualan atau kerugian. Selain itu juga dapat meningkatkan loyalitas nasabah yang akan melakukan transaksi secara berulang dan memberikan rekomendasi kepada orang lain serta tetap setia menjadi nasabah perbankan tersebut. Citra perbankan menjadi salah satu faktor yang mempengaruhi loyalitas nasabah. Citra yang baik akan dapat menimbulkan loyalitas nasabah pada perbankan. Hasil penelitian ini menunjukkan hasil yang positif dan signifikan antara citra perbankan dengan loyalitas nasabah. Penelitian ini sejalan dengan penelitian yang dilakukan oleh Azizah (2012) tentang pengaruh citra terhadap loyalitas nasabah BRI Cabang Semarang yang 
menyatakan bahwa variabel citra (X2) memiliki tingkat yang signifikan dan berpengaruh positif terhadap loyalitas nasabah.

\section{Pengaruh Kepuasan Nasabah (KN) terhadap Loyalitas Nasabah (LN)}

Kepuasan nasabah berpengaruh positif namun tidak signifikan terhadap loyalitas nasabah Kepuasan merupakan penilaian mengenai ciri atau keistimewaan produk atau jasa atau produk itu sendiri yang menyediakan tingkat kesenangan konsumen berkaitan dengan pemenuhan kebutuhan konsumen. Kepuasan nasabah merupakan salah satu tujuan utama yang ingin dicapai perusahaan, hal tersebut karena dengan adanya kepuasan yang dirasakan oleh pelanggan akan memberikan dampak jangka panjang, yaitu akan menjadikan pelanggan loyal kepada produk atau jasa perusahaan. Dengan adanya hal tersebut maka diharapkan akan tercipta loyalitas nasabah yang tercermin dari perilaku nasabah itu sendiri karena nasabah seringkali berpindah dari produk Bank satu ke produk Bank lain sehingga perlu dilakukan proteksi atas nasabah kaitannya dengan pencitraan dan sikap nasabah atas penerapan aktivitas sosial yang perusahaan lakukan.

Hal ini mengindikasikan bahwa meskipun nasabah PT Bank BRI Jayapura merasa puas akan layanan atau produk yang diberikan oleh bank tersebut, namun belum tentu hal tersebut dapat menjamin loyalitas nasabah. Hasil penelitian ini tidak mendukung penelitian sebelumnya yang dilakukan oleh Wahyuni (2008), Hidayat (2009) dan Sari, dkk (2011), menunjukkan bahwa variabel kepuasan mempunyai pengaruh yang positif dan signifikan terhadap loyalitas nasabah. Penelitian (Sulastri, 2015) menyimpulkan bahwa analisis data dalam penelitian menunjukkan variabel kepuasan mempunyai pengaruh yang positif dan signifikan terhadap loyalitas nasabah.

\section{PENUTUP}

\subsection{Kesimpulan}

Berdasarkan hasil penelitian mengenai Corporate Social Responsibility (CSR), corporate image, dan kepuasan nasabah terhadap loyalitas nasabah, maka dapat ditarik kesimpulan sebagai berikut: 1. Penerapan Corporate Social Responsibility (CSR) mempunyai pengaruh positif dan signifikan terhadap loyalitas nasabah, dimana diperoleh nilai koefisien bertanda positif sebesar 0,220 dan hasil uji statistik Ttest (uji parsial) menunjukkan nilai signifikansi variabel CSR yaitu sebesar 0,000 atau lebih kecil dari 0,05 .

2. Corporate image/citra perbankan mempunyai pengaruh positif dan signifikan terhadap loyalitas nasabah, dimana diperoleh nilai koefisien bertanda positif sebesar 0,461 dan hasil uji statistik Ttest (uji parsial) menunjukkan nilai signifikansi variabel corporate image sebesar 0,000 atau lebih kecil dari 0,05 .

3. Kepuasan nasabah mempunyai pengaruh positif namun tidak signifikan terhadap loyalitas nasabah, dimana diperoleh nilai koefisien bertanda positif sebesar 0,171 dan hasil uji statistik Ttest (uji parsial) menunjukkan nilai signifikansi variabel kepuasan nasabah sebesar 0,189 atau lebih besar dari 0,05.

\subsection{Saran}

Bagi peneliti selanjutnya, sebaiknya untuk memperluas penelitian yang akan dilakukan sehingga diperoleh informasi yang lebih lengkap tentang faktor-faktor apa saja yang mempengaruhi loyalitas nasabah. Selain itu sebaiknya peneliti menambah jumlah variabel mengingat penelitian ini hanya menggunakan tiga variabel independen,dan menggunakan metode lain agar data yang diperoleh tidak bias, serta menggunakan alat analisis yang berbeda sehingga informasi dan hasil yang didapatkan akan semakin lengkap dan akurat. 


\section{DAFTAR PUSTAKA}

A.B. Susanto, (2009), Reputation-Driven Corporate Social Responsibility, Jakarta: Esensi. Arikunto, Suharsimi. 2000. Manajemen Penelitian. Jakarta: Rineka Cipta.

Atmojo, Agung Purwo. 2010. Analisis Pengaruh Kualitas Layanan, Nilai Nasabah dan Atribut Produk Islam terhadap Kepuasan Nasabah (Studi Kasus pada BNI Syariah Cabang semarang). Skripsi. Dipublikasikan (Online). Semarang: Universitas Diponegoro, Fakultas Ekonomi, Jurusan Manajemen. (http://eprints.undip.ac.id/26399/1/skirpsi_komplit.pdf, Diakses 12 Mei 2015).

Badroen, Faisal, et al. 2006. Etika Bisnis dalam Islam. Jakarta: Kencana

Bank Rakyat Indonesia, (2014), CSR BRI, (http://csr.bri.co.id/tentang/)

Bawono, Anton. 2006. Multivariate Analysis Dengan SPSS. Salatiga: STAIN Salatiga Press.

Ghozali, Imam. 2013. Aplikasi Analisis Multivariate dengan Program IBM SPSS 21 Update PLS Regresi. Semarang: Badan Penerbit Undip, edisi ke-7.

Griffin, Jill. Tanpa Tahun. Costumer Loyalty: Menumbuhkan dan Mempertahankan Kesetiaan Pelanggan. Alih Bahasa Dwi Kartini Yahya. 2005. Jakarta: Erlangga

Hadi, Nor. 2011. Corporate Social Responsibility. Yogyakarta: Graha Ilmu.

Husein, Umar. 2003. Metode Penelitian untuk skripsi dan Tesis Bisnis. Jakarta: PT Gramedia Pustaka Utama, hlm.114.

Khaeril, dkk. 2012. Pengaruh Kualitas Layanan, Corporate Social Responsibility (CSR) terhadap Corporate Image serta Implikasinya terhadap Kepuasan Nasabah dan Loyalitas Nasabah di PT Bank Muamalat Indonesia Tbk. Cabang Makasar. Jurnal UNHAS, (Online), (http://pasca.unhas.ac.id/ jurnal/files/b3b1daf1d96c9d1f3454a0478ef87480.pdf, diakses 14 Desember 2014).

Irawan, Handi. 2002. 10 Prinsip kepuasan Pelanggan. Jakarta: PT Elex Media Komputindo.

Krismanto, Adi. 2009. Analisis Faktor-Faktor yang Mempengaruhi Loyalitas Nasabah (Studi Kasus pada PT. Bank Rakyat Indonesia Cabang Semarang Pattimura). Tesis. Dipublikasikan (Online). Semarang: Universitas Diponogoro, Program Studi Magister Manajemen. (http://eprints.undip.ac.id/16154/1/Adi_Krismanto.pdf, diakses 12 Mei 2015).

Muhadjirl dan Gita Fitri Q. 2011. Pengaruh Penerapan Corporate Social Responsibility terhadap Presepsi Nasabah Bank dan Dampaknya terhadap Corporate Image. Journal the Winners, (Online), Vol. 12, No. 2, 180-195, (http://library.binus.ac.id/eColls/eJournal/06\%20\%20Muhadjir.pdf, diakses 16 Mei 2015).

Nifita, Ade Titi., 2010. Pengaruh Citra BCA terhadap Loyalitas Nasabah Tabungan BCA Cabang Jambi. Jurnal Manajemen Pemasaran Modern, (Online), ISSN: 2085-0972, Vol. 2, No. 2, 158-169, (http://online.journal.unja.ac.id/index.php/pemasaran/article/view/128/111, diakses 7 Desember 2014).

Prasetya, Fanny Eka. 2010. Analisis Pengaruh Corporate Social Responsibility Lifebuoy Berbagi Sehat terhadap Loyalitas Konsumen dan Citra Perusahaan Unilever Indonesia (Studi Kasus di Kota Bogor). Skripsi. Dipublikasikan. Bogor: Institut Pertanian Bogor.

Putro, Rizki F. K. 2009. Pengaruh Kualitas Pelayanan terhadap Loyalitas Pelanggan dengan Kepuasan Pelanggan sebagai Variabel Pemediasi (Studi pada Pelanggan Fixed-Wire Phone di Surakarta). Skripsi. Dipublikasikan. Surakarta: Universitas Sebelas Maret, Jurusan Manajemn, Fakultas Ekonomi. (http://core.ac.uk/download/ pdf/12351975.pdf, diakses 22 Juli 2015).

Rahmasari, Deviana. 2012. Pengaruh Penerapan Corporate Social Responsibility terhadap Loyalitas Nasabah dengan Citra Perbankan dan Sikap Nasabah sebagai Variabel Intervening (Kasus pada PT Bank Rakyat Indonesia (Persero) Tbk. Abang Bantul). Skripsi. Dipublikasikan. Yogyakarta: Universitas Negeri Yogyakarta, Program Studi Akuntansi, Fakultas Ekonomi, (http://eprints.uny.ac.id/8677/, diakses 7 Desember 2014).

Rohmah, Aseeadatur. 2013. Penerapan Corporate Social Responsibility (CSR) terhadap Loyalitas Nasabah LKI Buana Kartika Mranggen. Skripsi. Dipublikasikan. Semarang: Institut Agama 
Islam Negeri Walisongo, Jurusan Ekonomi Islam, Fakultas Syarieah, (http://eprints.walisongo.ac. id/1794/, diakses 22 Oktober 2014).

Saputra, Falla Ilhami 2013. Kualitas Layanan, Kepercayaan, Komitmen dan Promosi Melalui Kepuasan Pelanggan (Studi Kasus Pada Bank BNI 46 Sentra Kredit Kecil Surabaya). Jurnal Aplikasi Manajemen, (Online), Vol. 11 No. 3 hal 445-457 (http://download.portalgaruda.org/article.php?artice=254217\&val=6848, diakses 14 Febuari 2014).

Saputri, Nurmaya. 2010. Analisis Corporate Social Responsibility sebagai Pembentuk Citra Perusahaan dan Pengaruhnya terhadap Loyalitas Pelanggan PT Fast Food Indonesia di Kota Semarang. Skripsi. Dipublikasikan (Online). Semarang: Universitas Diponogoro, Fakultas Ekonomi. (http://eprints.undip.ac.id/22462/, diakses 12 Desember 2015).

Sari, Syariah dkk. 2011. Pengaruh Corporate Social Responsibility (CSR) terhadap Kepuasan Nasabah dan Loyalitas Nasabah pada PT. Bank Danamon Indonesia, Tbk Makasar. Jurnal UNHAS, (Online), (http://pasca.unhas.ac.id/jurnal/files/8e4149edc45cd57dc.pdf, diakses 14 Desember 2014).

Sekaran, Umar. 2006. Research Methods for Business (Metodologi Penelitian untuk Bisnis). Jakarta: Salaemba Empat.

Seravina, Marisa. 2008. Pengaruh Penerapan Corporate Social Responsibility (CSR) terhadap Loyalitas Nasabah Tabungan Britama (Studi Kasus pada Nasabah PT. Bank Rakyat Indonesia (Persero) Tbk. Cabang Bogor). Skripsi. Dipublikasikan. Bogor: Institut Pertanian Bogor, Fakultas Ekonomi dan Manajemen,

Sugiyono. 2008. Metode Penelitian Kuantitatif Kualitatif R\&D. Bandung: Alfabeta, hlm. 7.

Sugiyono. 2011. Statistika untuk Penelitian. Bandung: CV. Alfabeta.

Sutisna. 2001. Perilaku dan Komunikasi Pemasaran. PT. Remaja Rosda Karya, Bandung.

Suwandi, Imam Mulyana Dwi. 2011. Citra Perusahaan. Seri Manajemen Pemasaran, www.eimam.uni.acc, (https://oeconomicus.files.wordpress. com/2007/07/citra-perusahaan.pdf, diakases 21 Mei 2015).

Usi, Usmara. 2008. Pemikiran Kreatif Pemasaran. Yogyakarta: Amara Books, hlm.122.

Wahyuni, Isti. 2008. Pengaruh Sistem Pelayanan dan Kepuasan terhadap Loyalitas Nasabah BMT Mitra Usaha Mulia Tempel Sleman. Skripsi. Dipublikasikan. Yogyakarta: Universitas Negeri Yogyakarta, Jurusan Manajemen Dakwah, Fakultas Dakwah, (http://digilib.uinsuka.ac.id/1591/1/BAB\%20I\%20BAB\%20IV\%20DAFTAR\%20PUST AKA.pdf, diakses 17 Desember 2014).

Widjaja, Gunawan dan Yeremia Ardi Pratama. 2008. Risiko Hukum\&Bisnis Perusahaan Tanpa CSR. Jakarta: Forum Sahabat.

Wibisono, Yusuf. 2007. Membedah Konsep \& Aplikasi CSR Corporate Social Responsibility.Gresik: Fascho Publishing. 